\title{
Метрологічне забезпечення озброєння та військової техніки на стадіях його життєвого циклу
}

\author{
Василь Биченков * 1 А; Володимир Коцюруба 2 А; Irop Власов 3 А \\ А Національний університет оборони України імені Івана Черняховського, м. Київ, Україна
}

Received: October 7, 2021 | Revised: October 19, 2021 | Accepted: October 30, 2021

DOI: $10.33445 /$ sds.2021.11.5.11

\begin{abstract}
Анотація
Підвищення ефективності виробництва і якості зразків озброєння та військової техніки не можливе без досягнення необхідної достовірності кількісної інформації про значення параметрів, які характеризують зразки озброєння, що розробляються, створюються та експлуатуються. Джерелами такої інформації $є$ вимірювання. Результати вимірювань будуть об'єктивними та достовірними тільки при правильній організації отримання вимірювальної інформації. Цього неможливо досяпти без належного метрологічного забезпечення.

В статті викладені загальні принципи метрологічного забезпечення як складової системи контролю якості зразків озброєння, описаний процес метрологічного забезпечення зразків озброєння та військової техніки на різних стадіях їх життєвого циклу, визначені основні цілі та завдання метрологічного забезпечення.

Важливість метрологічного забезпечення не обмежується його роллю щодо підвищення якості озброєння та військової техніки. Вимірювання лежать в основі процесів обліку витрат та раціонального використання матеріальних ресурсів, методів технічної діагностики та моніторингу процесу експлуатації озброєння та військової техніки.
\end{abstract}

Ключові слова: метрологічне забезпечення, життєвий цикл, озброєння та військова техніка, вимірювання.

\section{Постановка проблеми}

В сучасному суспільстві метрологія як наука про вимірювання та область практичної діяльності відіграє важливу роль. Це пов'язано з тим, що практично немає жодної сфери діяльності людини, де 6 не використовувались результати вимірювань. На основі вимірювань отримують інформацію про стан виробничих, економічних та соціальних процесів. 3 розвитком науки і техніки вимірювання все більше ускладняється, збільшується кількість вимірювань різноманітних величин. Вимірювання $\epsilon$ одним 3 шляхів пізнання природи людини, що об'єднують теорію 3 практичною діяльністю людини. Вони являються основою наукових знань, використовуються для обліку матеріальних ресурсів, забезпечення відповідної якості продукції, взаємозамінності деталей та вузлів, удосконалення технології, автоматизації виробництва, стандартизації, охорони здоров'я та забезпечення безпеки праці й для багатьох інших галузей діяльності людини, включаючи й оборону держави.

Разом з тим важливу роль в розвитку озброєння та військової техніки відіграє його метрологічне забезпечення, яке визначає фактичні параметри при проектуванні, виробництві, експлуатації та утилізації зразків озброєння.

\footnotetext{
1 * Corresponding author: доктор технічних наук, старший науковий співробітник, заступник начальника центру, е-таil: kadet97@ukr.net, ORCID: 0000-0002-6080-6976

2 доктор технічних наук, професор, професор кафедри, e-mail: kotcuru@ukr.net.net, ORCID: 0000-0001-6565-9576

3 кандидат військових наук, доцент, начальник кафедри, e-mail: vlasov_igor_69@ukr.net, ORCID: 0000-0003-3680-1347
} 


\section{Аналіз останніх досліджень та публікацій}

В останніх публікаціях розглядались питання метрологічного забезпечення експлуатації озброєння та військової техніки, проте не висвітлювались питання організації та проведення метрологічного забезпечення на етапах розробки, випробувань, виробництва та утилізації зразків озброєння, не аналізується нормативне підґрунтя метрологічного забезпечення зазначених етапів життєвого циклу озброєння та військової техніки $[10,11,12]$.

\section{Постановка завдання}

Метрологічне забезпечення - широке поняття, що потребує обов'язкового уточнення в залежності від завдань, які перед ним ставляться. Допускається застосування термінів "метрологічне забезпечення вимірювань", "метрологічне забезпечення виробництва", "метрологічне забезпечення систем якості", "метрологічне забезпечення стандартизації" тощо. В контексті здійснення метрологічного забезпечення озброєння та військової техніки необхідно конкретизувати поняття метрологічного забезпечення в рамках відповідних стадій життєвого циклу зразків озброєння.

Отже, метою статті $\epsilon$ окреслення завдань процесу метрологічного забезпечення озброєння та військової техніки, проаналізувати нормативно-правові основи метрологічного забезпечення озброєння та військової техніки на всіх стадіях його життєвого циклу.

метрологічного забезпечення в Міністерстві оборони України та Збройних Силах України, Державних стандартів України: ДСТУ 2568-94, ДСТУ 2681-94, ДСТУ 3231:2007, ДСТУ ISO 10012:2005, ДСТУ STANAG 4704:2018 та інших керівних документів.

Метрологічне забезпечення (Мл3) - це комплекс заходів, спрямованих на досягнення єдності вимірювань та достовірності контролю параметрів об'єктів вимірювань військового призначення у 3 С України, інших військових формувань.

В широкому сенсі МлЗ розглядається як область, що охоплює теорію, методи, засоби та організаційні правила забезпечення єдності і точності вимірювань, контролю та випробувань з метою забезпечення високої ефективності виробництва, експлуатації технічних об'єктів та достовірності наукового експерименту. У вузькому сенсі під Мл3 розуміють роботу метрологічних служб, а іноді й роботи по проведенню високоточних вимірювань, створення спеціальних контрольно-вимірювальних та випробувальних пристроїв конкретного 
застосування [1-3]

Метрологічне забезпечення супроводжує озброєння та військову техніку (ОВТ) на всіх стадіях його життєвого циклу, що містить:

1) Дослідження та обгрунтування необхідності розробки

- розробка технічної пропозиції;

- розробка, узгодження та затвердження технічного завдання.

2) Розробка

- розробка ескізного проекту;

- розробка технічного проекту;

- розробка конструкторської документації;

- виготовлення дослідного зразка озброєння (складової частини) та проведення попередніх випробувань;

- підготовка до державних випробувань;

- державні випробування.

3) Виробництво

4) Експлуатація

5) Капітальний ремонт

6) Утилізація.

Розглянемо основну мету і завдання Мл3, що вирішуються на кожній стадії життєвого циклу ОВТ.

Перша стадія життєвого циклу дослідження та обґрунтування необхідності розробки. На цій стадії основною метою МлЗ $\epsilon$ досягнення необхідних характеристик зразків озброєння, що розробляються шляхом обґрунтованого вибору методів вимірювань, визначення сукупності характеристик та параметрів, які підлягають вимірюванням, визначення значень допустимих відхилень кожного параметру, з врахуванням умов проведення вимірювань, використання необхідних засобів, що забезпечують надійні та достовірні вимірювання і контроль обраних параметрів ОВT, а також обробку їх результатів стандартними або вперше розробленими методиками.

Основні завдання Мл3 в процесі дослідження та обґрунтування розробки наступні:

- попереднє визначення номенклатури параметрів зразка озброєння та його складових частин, які потребують

вимірювання, нормування визначених параметрів, визначення вимог до похибок вимірювання параметрів;

- визначення номенклатури параметрів, що контролюються в процесі експлуатації;

- оцінка можливостей існуючого парку засобів вимірювальної техніки військового призначення (ЗВТВП) для метрологічного забезпечення озброєння та військової техніки;

- розробка пропозицій з МлЗ випробувань зразків озброєння;

- організація проведення, при необхідності, комплексу науково-дослідних та дослідно-конструкторських робіт по розробці нових ЗВТВП;

- організація і проведення метрологічної експертизи матеріалів технічної пропозиції та технічного завдання й розробка плану заходів щодо усунення виявлених недоліків.

Друга стадія життєвого циклу ОВТ розробка. Метою метрологічного забезпечення на цій стадії є:

- встановлення (вибір) параметрів зразка озброєння, що підлягають вимірюванню та вимірювальному контролю при випробуваннях, виробництві та експлуатації, а також параметрів технологічних процесів, що контролюються в ході виробництва;

- вибір засобів, які забезпечують вимірювання, контроль визначених параметрів та характеристик ОВТ, що розробляються, а також технологічних процесів із заданою точністю;

- розробка методів випробувань та виготовлення ЗВТВП, яких не вистачає.

Основні задачі метрологічного забезпечення на стадії розробки:

- визначення та обґрунтування переліку параметрів та характеристик ОВТ, що розробляється, його складових частин, допустимих відхилень параметрів, що вимірюються, похибки вимірювань на основі аналізу заданих технічних характеристик зразків озброєння;

- обґрунтування переліку параметрів, що 
підлягають контролю в процесі експлуатації та вимог щодо достовірності контролю;

- організація, при необхідності, науководослідних та дослідно-конструкторських робіт по разробці проблемних питань вимірювань та Мл3 процесів вимірювання, нових засобів вимірювання, контролю та випробувань;

- встановлення вимог щодо повірки (калібрування) ЗВТВП, що входять до складу ОВТ, розробка методик повірки;

- виявлення особливостей Млз ОВТ та його складових частин;

- розробка розділів (пунктів) конструкторської та технологічної документації дослідного зразка озброєння (що стосуються питань Мл3)), системи контролю технічного стану ОВТ;

- проведення метрологічної експертизи конструкторської та технологічної документації на ОВТ та його складові частини (якщо це визначено у відповідних документах);

- аналіз стану та організація робіт по Мл3 виробництва;

- оцінка реальної точності вимірювань та достовірності контролю основних параметрів;

- забезпечення ЗВТВП засобами їх повірки (калібрування);

- участь у розробці програми і методик державних випробувань;

- перевірка готовності Мл3 державних випробувань.

При проведенні державних випробувань здійснюється:

перевірка відповідності МлЗ експлуатації ОВТ вимогам технічного завдання у відповідності до програми и методики державних випробувань;

- визначення фактичних значень основних параметрів й оцінка відповідності отриманих значень заданим;

- проведення метрологічної експертизи ОВТ (у випадках, передбачених відповідними нормативними документами), розробка заходів та усунення недоліків, викладених в акті державних випробувань.

В ході Мл3 виробництва ОВТ необхідні показники якості досягаються за допомогою вимірювального контролю кожної операції технологічного процесу. На цьому етапі виконуються роботи по автоматизації процесів вимірювання та вимірювального контролю, проводиться аналіз та визначаються методи і засоби вимірювання у технологічних процесах, розробляються методики виконання вимірювань i проводиться їх атестація, якщо це передбачено відповідними нормативними документами, технологічні процеси та технічна документація підлягають метрологічній експертизі. Разом з тим під час виробництва ОВТ однією з важливих задач Мл3 є виявлення порушень вимог щодо процесу виробництва.

Для запобігання цих порушень необхідно оснастити промислове обладнання вимірювальними засобами, які слідкували 6 за його станом і станом оброблюючого інструменту. Також у автоматизованому виробництві все більш широкого застосування знаходять роботи, можливості яких в значній мірі визначаються здібностями орієнтуватися у навколишньому середовищі, пристосовуватися до неї та реагувати на ї̈ зміни. Для цього вони повинні мати у своєму складі вимірювальні пристрої.

Тому, при управлінні якістю виробництва все більше уваги приділяється контрольованості (спостерігаємості) технологічного процесу.

Основною метою МлЗ ОВТ в процесі виробництва $€$ випуск виробником ОВТ, що відповідає вимогам конструкторської, технологічної і нормативної документації, а також попередження виробничого браку та отримання інформації про якість готових зразків ОВТ і стан технологічного процесу.

Як було вказано вище, Мл3 ОВТ здійснюється на всіх стадіях життєвого циклу ОВТ. Проте основна маса засобів вимірювання і контролю використовується в процесі експлуатації ОВТ для контролю й 
прогнозування їх технічного стану, пошуку відмов та несправностей, вимірювання характеристик, настроювання, калібрування, юстування та регулювання.

Метрологічне забезпечення експлуатації ОВТ - це комплекс наукових та організаційнотехнічних заходів, що направлені на виконання точних та своєчасних вимірювань, дотримання єдності, необхідної точності вимірювань та підвищення достовірності вимірювального контролю параметрів в процесі експлуатації ОВТ.

На цій стадії МлЗ вирішує наступні основні задачі:

- підготовка рекомендацій щодо удосконалення МлЗ експлуатації ОВТ;

- формування парку ЗВТВП, своєчасне проведення їх повірки (калібрування);

- ремонт, зберігання засобів вимірювання;

- проведення робіт по удосконаленню методів передачі розмірів одиниць фізичної величини від еталонів до робочих засобів вимірювання;

- обслуговування, зберігання та удосконалення еталонів;

- підготовка кадрів 3 питань метрологічного забезпечення;

- перевірка стану Млз ОВТ.

На всіх етапах життєвого циклу продукції проводять технічне обслуговування технічної бази Млз, що являє собою комплекс робіт по підтриманню іï справності та роботопридатності.

Мета МлЗ на стадії "капітальний ремонт" - забезпечити відповідність Млз прогресивним методикам виконання вимірювань.

До основних задач Мл3 при капітальному ремонті відносяться:

- аналіз Млз ремонтного виробництва;

- уточнення конструкторської та ремонтної технологічної документації, значень параметрів, що контролюються, а також параметрів та характеристик технологічних процесів ремонту, які підлягають вимірюванню або контролю з нормуючою точністю в певних умовах виконання

вимірювань;

- забезпечення нормальних умов проведення вимірювань (температурний режим, електромагнітні поля, напруга, струм тощо);

- впровадження нових методик вимірювання;

- забезпечення ремонтних органів засобами вимірювання;

- метрологічний нагляд за дотриманням метрологічних норм і правил, за станом й правильністю застосування засобів вимірювання.

Від рівня Мл3 на цьому етапі залежить ефективність і якість капітального ремонту OBT.

Заключний етап життєвого циклу ОВТ "утилізація" - одна з найбільших проблем сучасності. Утилізація набула за своїми масштабами державного значення.

Мета Млз цієї стадії - перехід від процесів простого знищення ОВТ (ліквідації) до промислової утилізації, в результаті якої можуть отримати "друге життя" не тільки комплектуючі деталі, агрегати, системи, але й увесь зразок ОВТ в цілому.

Метрологічне забезпечення на цьому етапі надає можливість використання ОВТ, які відповідають вимогам надійності і якості при їх подальшій експлуатації. Метрологічне забезпечення повинно забезпечити надійні і якісні вимірювання, відповідні аналітичні дослідження складу ОВТ, що утилізуються. За своїм сенсом утилізація $\epsilon$ таким же технологічним процесом, як і виробництво OBT.

Основною задачею Мл3 на етапі "утилізація" $є$ створення таких умов, при яких забезпечується можливість використання тільки тих зразків озброєння або окремих їх складових частин, які відповідають вимогам надійності, якості та безпеки для життя та здоров'я людей і навколишнього середовища при подальшій експлуатації. 


\section{Висновки}

Правильне розуміння необхідності та важливості мети і задач Мл3 ОВТ на всіх стадіях його життєвого циклу дозволяє організувати належне метрологічне забезпечення ОВТ що розробляється, створюється та експлуатується, без чого неможна досягти високої боєготовності ОВТ, його якості, надійності, та конкурентоспроможності.

\section{Список використаних джерел}

1. Про метрологію та метрологічну діяльність: Закон України (із змінами) (від 05.06.2014 № 1314-VII).

2. Про особливості забезпечення єдності вимірювань у сфері оборони України: Постанова Кабінету Міністрів України від 23.12.2015 № 1152.

3. Положення про метрологічну службу Міністерства оборони України та 3бройних Сил України: затв. Наказом Міністерства оборони України від 24.05.2017 р. № 288.

4. Керівництво 3 організації та порядку експлуатації вимірювальної техніки у Збройних Силах України: затв. Наказом заступника Міністра оборони з озброєння - начальника Озброєння Збройних Сил України від 01.06.2001 № 79.

5. Тимчасова інструкція про уповноваження військових метрологічних лабораторій: затв. Наказом начальника Центрального управління метрології і стандартизації Збройних Сил України Озброєння Збройних Сил України - головного метролога Збройних Сил України від 08.10.2018 № 7.

6. Інструкція 3 організації метрологічного обслуговування спеціальної контрольноперевірочної апаратури: затв. Наказом Міністерства оборони України від 19.12.2014 № 907.
7. Перелік військової вимірювальної техніки, що підлягає повірці (атестації) в Збройних Силах України: затв. Наказом Міністра оборони України від 26.11.1994 № 278.

8. ДСТУ ISO 9001:2015. Система управління якістю. Вимоги // Державний стандарт України. - Київ: Держстандарт, 2015, 32 с.

9. ДСТУ-Н РМГ 63:2013. Забезпечення ефективності вимірювання під час керування технологічними процесами. Метрологічна експертиза технологічної документації. Видання друге // Державний стандарт України. - Київ: Мінекономрозвитку України, 2015, 14 с.

10. Гонсьор О. Й., Микийчук М. М. Метрологічне забезпечення якості виробництва // Львів: Видавництво Держ. ун-ту «Львівська політехніка», 2012, С. 202205.

11. Пупань Л. И., Федорович В. А. Метрологическое обеспечение качества продукции. Учебное пособие // Харьков: НТУ “ХПИ", 2019, 149 с.

12. Бабков Ю. П. Основы теории надежности, технического обслуживания и ремонта вооружения и военной техники войск ПВО Сухопутных войск : уч.пособие / Бабков Ю.П. - Харьков : ХВУ, 1996. - 237 с.

\section{Метрологическое обеспечение вооружения и военной техники на стадиях его жизненного цикла}

\footnotetext{
Василий Быченков * 1 А; Владимир Коцюруба 2 А; Игорь Власов 3 А;

* Corresponding author: ${ }^{1}$ доктор технических наук, старший научный сотрудник, заместитель начальника центра, е-таil: kadet97@ukr.net, ORCID: 0000-0002-6080-6976

2 доктор технических наук, профессор, профессор кафедры, e-mail: kotcuru@ukr.net, ORCID: 0000-0001-6565-9576

${ }^{3}$ кандидат военных наук, доцент, начальник кафедры e-mail: vlasov_igor_69@ukr.net, ORCID: 0000-0003-3680-1347

А Национальный университет обороны Украины имени Ивана Черняховского, Киев, Украина
} 


\begin{abstract}
Аннотация
Повышение эффективности производства и качества образцов вооружения и военной техники невозможно без достижения необходимой достоверности количественной информации о значениях параметров, характеризующих разрабатываемые, создаваемые $и$ эксплуатируемые образцы вооружения. Источниками такой информации есть измерения. Результаты измерений будут объективны и достоверны только при правильной организации получения измерительной информации. Этого невозможно добиться без должного метрологического обеспечения.

В статье изложены общие принципы метрологического обеспечения как составляющей системы контроля качества образцов вооружения, описан процесс метрологического обеспечения образцов вооружения и военной техники на разных стадиях их жизненного цикла, определены основные цели и задачи метрологического обеспечения.

Важность метрологического обеспечения не ограничивается его ролью в повышении качества вооружения и военной техники. Измерения лежат в основе процессов учета затрат и рационального использования материальных ресурсов, методов технической диагностики и мониторинга эксплуатации вооружения и военной техники.
\end{abstract}

Ключевые слова: метрологическое обеспечение, жизненный цикл, вооружение и военная техника, измерения.

\title{
Metrological support of weapons and military equipment at the stages of its life cycle
}

\author{
Vasyl Bychenkov * 1 A; Volodymyr Kotsyuruba 2 A; Igor Vlasov ${ }^{3 \mathrm{~A}}$ \\ * Corresponding author: ${ }^{1}$ Dr of Technical Sciences, Senior Researcher, Deputy Head of the Center, e-mail: kadet97@ukr.net, ORCID: 0000-0002-6080-6976 \\ ${ }^{2}$ Dr of Technical Sciences, Professor, Professor of the Department, e-mail: kotcuru@ukr.net, ORCID: 0000-0001-6565-9576 \\ ${ }^{3}$ Candidate of Military Sciences, Associate Professor, Head of the Department, e-mail: vlasov_igor_69@ukr.net, ORCID: 0000-0003-3680-1347 \\ A National University of Defense of Ukraine named after Ivan Chernyiakhovskyi, Kyiv, Ukraine
}

\begin{abstract}
An increase in the production efficiency and quality of weapons and military equipment is impossible without achieving the necessary reliability of quantitative information on the parameter's values characterizing the weapons being developed, created and operated. Sources of such information are measurements. The measurement results will be objective and reliable only if the measurement information is received correctly. This cannot be achieved without proper metrological support.

The article outlines the general principles of metrological support as a component of the quality control system for weapons samples, describes the process of metrological support for weapons and military equipment at different stages of their life cycle, defines the main goals and objectives of metrological support.

The importance of metrological support is not limited to its role in improving the weapons and military equipment quality. Measurements underlie the accounting processes for costs and the rational use of material resources, technical diagnostics and monitoring methods of the weapons and military equipment operation.
\end{abstract}

Keywords: metrological support, life cycle, weapons and military equipment, measurements.

\section{References}

1. On Metrology and Metrological Activity: Law of Ukraine (as amended) (dated 05.06.2014 № 1314-VII).

2. On the peculiarities of ensuring the unity of measurements in the field of defense of Ukraine: Resolution of the Cabinet of Ministers of Ukraine dated 23.12.2015 № 1152. 
3. Regulations on the metrological service of the Ministry of Defense of Ukraine and the Armed Forces of Ukraine: approved. Order of the Ministry of Defense of Ukraine dated 24.05.2017 № 288.

4. Guide on the organization and operation of measuring equipment in the Armed Forces of Ukraine: approved. By order of the Deputy Minister of Defense for Armaments - Chief of the Armaments of the Armed Forces of Ukraine dated 01.06.2001 № 79.

5. Temporary instruction on authorization of military metrological laboratories: approved by the Order of the Head of the Central Department of Metrology and Standardization of the Armed Forces of Ukraine Armament of the Armed Forces of Ukraine - Chief Metrologist of the Armed Forces of Ukraine dated 08.10.2018 № 7.

6. Instruction on the organization of metrological maintenance of special control and testing equipment: approved by the Order of the Ministry of Defense of Ukraine dated 19.12.2014 № 907.

7. The list of military measuring equipment subject to verification (certification) in the
Armed Forces of Ukraine: approved by the Order of the Minister of Defense of Ukraine dated 26.11.1994 № 278.

8. DSTU ISO 9001:2015. Quality management system. Requirements // State Standard of Ukraine. - Kyiv: State Standard, 2015, 32 p.

9. DSTU-N RMG 63: 2013. Ensuring the efficiency of measurement during the management of technological processes. Metrological examination of technological documentation. Second edition // State Standard of Ukraine. - Kyiv: Ministry of Economic Development of Ukraine, 2015, 14 p.

10. Gonsor O. Y., Mikiychuk M. M. Metrological quality production assurance // Lviv: State Publishing House. Lviv Polytechnic University, 2012, Pp. 202-205.

11. Pupan L.I., Fedorovich V.A. Metrological quality assurance of products. Textbook // Kharkiv: NTU “KhPI", 2019, 149 p.

12. Babkov Yu.P. Fundamentals of the theory of reliability, maintenance and repair of weapons and military equipment of the Air Defense Forces of the Ground Forces: manual / Babkov Yu.P. - Kharkov: KhVU, 1996. 237 p. 